International

Medical Society

http://imedicalsociety.org

\title{
Pressure Injuries:
}

\section{Predisposing Conditions and Risk Factors in Adult ICU \\ ORIGINAL}

Francisca Patrícia Barreto de Carvalho', Clélia Albino Simpson², Lucídio Clebeson de Oliveira1, Francisco Rafael Ribeiro Soares ${ }^{1}$, Glauber Weder dos Santos Silva ${ }^{2}$, Romeika Carla Ferreira de Sena ${ }^{2}$, Fábio Claudiney da Costa Pereira ${ }^{3}$, Tássia Regine de Morais Alves ${ }^{1}$, Ana Maria Carvalho Pinheiro ${ }^{4}$, Francisco Arnoldo Nunes de Miranda ${ }^{2}$

\section{Abstract}

Introduction: Pressure lesions are localized damage in skin and/or underlying soft tissue, usually over a bony prominence or related to a medical device or other device. In Intensive Care Units patients are critically susceptible to the development of lesions by pressure, for various reasons.

Objective: To identify predisposing conditions and risk factors of pressure ulcers in patients admitted to an Intensive Care Unit of a mid-sized general hospital in the Western region of the State of Rio Grande do Norte (RN), Brazil.

Method: Nonparticipating observational study with documentary stage, of prospective longitudinal type, performed in ICU of adult kind of a General Hospital in the city of Mossoró-RN, Brazil. Data collection took place on alternate days during 43 days between May and June 2012. The research protocol was approved by the CEP/UERN under opinion No. 67606/12.

Results: The intrinsic risk factors for the emergence of the most evident pressure injuries were decreased pain sensitivity, reduced turgor and elasticity, evidenced bony prominences and impaired physical mobility. Extrinsic risk factors were the pressure force on the body and forces of friction and shear. The chronic obstructive pulmonary disease, impaired motor skills and evidenced bony prominences, specifically in the sacral region, were statistically significant factors in association with the development of pressure injuries.
1 State University of Rio Grande do Norte. Mossoró, RN, Brazil.

2 Federal University of Rio Grande do Norte. Natal, RN, Brazil.

3 FACEX University Center. Natal, RN, Brazil.

4 Nova Esperança Nursing School. Mossoró, RN, Brazil.

Contact information:

\section{Francisca Patrícia Barreto de} Carvalho.

Address: Street Pinto Martins, $n^{0} 1044$, District Areia Preta. Natal/RN, Brazil. CEP 59014-060

” patriciabarreto36@gmail.com 
Conclusions: To provide a comprehensive and qualified assistance, it is necessary to invest in improvement of the assistance provided through the adoption of appropriate measures for customer care, education and multidisciplinary team training, as well as the participation of the institution with the promotion of appropriate work conditions for the multidisciplinary team, promoting qualified assistance to the patient.

\section{Keywords}

Pressure Ulcer; Risk Factors; Intensive Care Units.

\section{Introduction}

Pressure lesions (PL) are localized damage in skin and/or underlying soft tissue, usually over a bony prominence or related to a medical device or other device. The injury can be presented as intact skin or an open ulcer, and can be painful. The injury occurs as a result of an intense and/or prolonged pressure or pressure in combination with shear. The soft tissue tolerance for pressure and shear can also be affected by microclimate, nutrition, perfusion, comorbidities and the state of the soft tissue [1].

In Intensive Care Units (ICU) patients are criticaIly susceptible to development of $\mathrm{PL}$, because of the chronicity of the disease, its severity, the high average length of stay in hospital, frequent therapy procedures, immobility in bed, specific device connection, loss of muscle mass, long periods of hospitalization and, above all, the high degree of dependence of the patients, taking them into immobility in bed [3].

$\mathrm{PL}$ are also the gateway to infections, complicate recovery, increasing considerably nursing staff work, treatment costs, delay in hospital discharge and they may contribute to mortality in certain patients. It develops in a short time and prevention is the preferred management strategy for people who are at risk to develop it. Its prevalence is one of the important indicators of risk assessment and preventive measures in order to avoid $\mathrm{PL}$, and it has been included as one of the indicators of Quality of Nursing Assistance [4].
In order to conduct preventive measures tailored to each patient, assessing the risk of developing PL must be continuous, because it is imperative for the effective implementation of preventive measures based on clinical evidence and cost [5]. The assessment by means of validated scales should be continuously carried out because it can prevent the onset of PL in other places, as well as the worsening of those already existing [6].

From the preventive point of view, it is important to not only be aware of the morbidity of pressure ulcers, but also explore the full spectrum of demographic and biological markers that may be related to its development. Furthermore, there are no studies that assess the risks, the incidence and prevalence of $\mathrm{PL}$ at the location of the country proposed for this study, making it difficult to determine a strategic assistance in order to reduce its prevalence and hospital costs in relation to the treatment and recovery, as well as the suffering and the worsening of the clinical condition of patients in this reality. Nursing can and should use this knowledge and tools to protect patients from PL and other complications in ICU everyday life. Thus, this study aimed to identify predisposing conditions and risk factors of pressure ulcers in patients admitted to an Intensive Care Unit of a mid-sized general hospital in the Western region of the State of Rio Grande do Norte (RN), Brazil. 


\section{Materials and Methods}

This is a nonparticipating observational study with documentary stage, of prospective longitudinal type. It had an exploratory-descriptive quantitative approach with the purpose to identify the incidence and the verification of existing association between extrinsic and intrinsic factors, and predisposing conditions related to occurrence of UP in patients admitted to ICU.

The documentary research involves investigation of original documents that did not receive analytic treatment, aiming to extract information to be categorized and subsequently analyzed [9]. It took place on the charts collection from users of the sectors I and II of ICU adult type of a general hospital in the city of Mossoró-RN, Brazil, with capacity of 20 beds in total occupation, aimed at patients who need intensive therapy for various kinds of diseases.

Population and sample were constituted of all those who were admitted in the searched sector, given the following inclusion criteria: (1) been older than 18 years and (2) do not presenting PL at the time of admission to the ICU. Those patients admitted with other injuries in locations known to be prone to PL were excluded, because these could be confounding factors for the research. These 50 patients' criteria were embedded in the established collection period.

A form was used, adapted and based on the Fernandes' [3] form, comprising the following steps: Completing the demographic data, informative caption on the abbreviations to Predisposing Conditions (CP), Intrinsic Risk Factors (FI) and Extrinsic Risk Factors (FE). It is also composed by two parts of investigation of the risk factors for the emergence of UP, considering that the first will be investigated only once on each individual admitted to the ICU and the second will be investigated once every two days in the same individuals.

Data collection occurred on alternate days in each of the sectors and the entire collection period comprised 43 days in May and June 2012. The re- search protocol was approved by the Committee of Ethics in Research with Human Beings of the University of Rio Grande do Norte State, under opinion No. 67606 in 07 August 2012 and CAEE $n^{\circ}$ 05096612.3.0000.5179. The Informed Consent Term has been signed by the legal guardians of the participants, identified in their records and in times of visits in the days leading up to the collection.

The subjects were evaluated at first as the demographic data; predisposing metabolic, cardiorespiratory, neurological, chronic noncommunicable conditions; age intrinsic factor and mattress extrinsic factor. This evaluation was performed only once.

The other predisposing conditions, intrinsic and extrinsic risk factors were assessed in each patient every two days until the emergence of a PL, thus creating the effect of the appearance of this disease. On the observational approach, patients admitted in the ICU were monitored and evaluated via anamnesis, physical examination of the skin and clinical-dermatological on alternate days, later, obtaining the data, we carried out registration and descriptive analysis.

The calculation of incidence was based on the ratio between the number of new cases, i.e., the number of patients who have acquired pressure ulcers after admission to the ICU and the total of subjects in the sample. The documentary survey was conducted through the medical records of patients selected to collect information related to the diagnosis, age, laboratory test results, record of evolution, medical and nursing prescription. The end result of this ratio was multiplied by one hundred so that the results were expressed in percentages.

Data were organized into Microsoft Office Exce/ ${ }^{\circledR}$ spreadsheets in order to undergo descriptive statistics being expressed as averages, standard deviation, as well as frequency, maximum and minimum values, analyzed by SPSS 17.0 statistical software.

The risk factors that influence the development of pressure ulcers in patients admitted were calculated by odds ratio (OR) and 95\% confidence interval 
with significance for the Chi-square test or Fisher exact test, when the expected frequencies were less than 5 . Then, a multivariate logistic regression model was elaborated, in order to verify the mutual influence of factors involved in the development of ulcers. Statistical significance level of $p<0,05$ was established.

\section{Results}

We followed 50 patients admitted to two ICUs in the searched the hospital, for a period of 43 consecutive days. Of these, 11 patients have developed PL. 08 (72.7\%) of them were female, while 03 (27.3\%) were male. The incidence was prevalent in women, with no significant association between gender and the appearance of ulcers ( $p=0.088$ ).

It was found that all 11 (100\%) patients with PL were 60 years old or older. There was a statistically significant pattern in relation to patients with Chronic Obstructive Pulmonary Disease (COPD), being that of the 11 patients affected by $\mathrm{PL}, 08$ (72.7\%) presented COPD, with high relevance to the emergence of pathology proposing a risk of over 12 times $(O R=1.020 ; I C=0.254-4.104 ; p=$ 0.977) (Table 1).

With respect to altered sensitivity surface which corresponds to an intrinsic risk factor for the onset of $\mathrm{PL}$, it was found that the decreased pain sensitivity presented more significance $(p=0.007)$, and 09 (81.8\%) of them had a deficit (Table 2 ).

All $11(100 \%)$ patients with UP presented reduced turgor and elasticity, with statistical significance as risk factor of ( $p=0.022$ ) (Table 3 ).

The sacral and coccygeal region are statistically more significant, being that the sacral region was evidenced in 09 (81.8\%) of 11 patients who have developed UP, and the coccygeal region was also evidenced in 09 (81.8\%) of these patients (Table 4).

Among the 11 patients, 08 (72.7\%) of them had inability to move in the bed, with statistical significance of $(p=0.42)$. As for strength, control and/or
Table 1. Occurrence of UP according to the predisposing conditions: Metabolic, cardiorespiratory, neurological and chronic non-communicable diseases.

\begin{tabular}{|c|c|c|c|c|c|}
\hline Variables & $n$ & $\%$ & OR & IC- $95 \%$ & p \\
\hline \multicolumn{6}{|l|}{ Diabetes } \\
\hline Yes & 04 & 36.4 & \multirow{2}{*}{1.020} & \multirow{2}{*}{$0.254-4.104$} & \multirow{2}{*}{0.977} \\
\hline No & 07 & 63.6 & & & \\
\hline \multicolumn{6}{|l|}{ COPD } \\
\hline Yes & 08 & 72.7 & \multirow{2}{*}{12.190} & \multirow{2}{*}{$2.565-57.936$} & \multirow{2}{*}{$<0.01 *$} \\
\hline No & 03 & 27.3 & & & \\
\hline \multicolumn{6}{|l|}{ ICC } \\
\hline Yes & 02 & 18.2 & \multirow{2}{*}{0.356} & \multirow{2}{*}{$0.067-1.875$} & \multirow{2}{*}{0.292} \\
\hline No & 09 & 81.8 & & & \\
\hline
\end{tabular}

Source: Field research, 2012.

Table 2. Occurrence of UP according to intrinsic factors: Evaluation of superficial changes.

\begin{tabular}{|c|c|c|c|c|c|}
\hline Variables & $\mathrm{n}$ & $\%$ & OR & IC- $95 \%$ & p \\
\hline \multicolumn{6}{|c|}{ Tactile sensitivity decreased/absent } \\
\hline Yes & 09 & 81.8 & \multirow{2}{*}{4.275} & \multirow{2}{*}{$0.816-22.390$} & \multirow{2}{*}{0.07} \\
\hline No & 02 & 18.2 & & & \\
\hline \multicolumn{6}{|c|}{ Thermal sensitivity decreased } \\
\hline Yes & 08 & 72.7 & \multirow{2}{*}{3.111} & \multirow{2}{*}{$0.716-13.513$} & \multirow{2}{*}{0.175} \\
\hline No & 03 & 27.3 & & & \\
\hline \multicolumn{6}{|c|}{ Decreased pain sensitivity } \\
\hline Yes & 09 & 81.8 & \multirow{2}{*}{8.036} & \multirow{2}{*}{$1.519-42.517$} & \multirow{2}{*}{0.007} \\
\hline No & 02 & 18.2 & & & \\
\hline
\end{tabular}

Source: Field research, 2012.

Table 3. Occurrence of UP according to intrinsic factors: Evaluation of changes in turgor and elasticity of the skin.

\begin{tabular}{|l|c|c|c|c|c|}
\hline Variables & $\mathbf{n}$ & $\%$ & OR & IC- $95 \%$ & $\mathbf{p}$ \\
\hline Decreased turgor and elasticity \\
\hline Yes & 11 & 100 & - & - & 0.022 \\
\hline No & 0 & 0 & & & \\
\hline
\end{tabular}

Source: Field research, 2012. 
Table 4. Occurrence of UP according to intrinsic factors: Evaluation of evidenced bony prominences.

\begin{tabular}{|c|c|c|c|c|c|}
\hline Variables & $\mathrm{n}$ & $\%$ & OR & IC- $95 \%$ & $p$ \\
\hline \multicolumn{6}{|l|}{ Iliac crests } \\
\hline Yes & 04 & 36.4 & \multirow{2}{*}{5.00} & \multirow{2}{*}{$1.003-24.914$} & \multirow{2}{*}{0.059} \\
\hline No & 07 & 63.6 & & & \\
\hline \multicolumn{6}{|c|}{ Shoulder blade } \\
\hline Yes & 04 & 36.4 & \multirow{2}{*}{1.143} & \multirow{2}{*}{$0.283-4.622$} & \multirow{2}{*}{0.851} \\
\hline No & 07 & 63.6 & & & \\
\hline \multicolumn{6}{|l|}{ Sacrum } \\
\hline Yes & 09 & 81.8 & \multirow{2}{*}{7.200} & \multirow{2}{*}{$1.366-37.960$} & \multirow{2}{*}{$0.011^{*}$} \\
\hline No & 02 & 18.2 & & & \\
\hline \multicolumn{6}{|l|}{ Coccyx } \\
\hline Yes & 09 & 81.8 & \multirow{2}{*}{5.824} & \multirow{2}{*}{$1.110-30.559$} & \multirow{2}{*}{$0.025^{*}$} \\
\hline No & 02 & 18.2 & & & \\
\hline \multicolumn{6}{|l|}{ Calcaneus } \\
\hline Yes & 09 & 81.8 & \multirow{2}{*}{0.818} & \multirow{2}{*}{$0.141-4.765$} & \multirow{2}{*}{0.823} \\
\hline No & 02 & 18.2 & & & \\
\hline
\end{tabular}

Source: Field research, 2012.

Table 5. Occurrence of UP according to intrinsic factors: Evaluation of impaired physical mobility.

\begin{tabular}{|c|c|c|c|c|c|}
\hline Variables & $\mathrm{n}$ & $\%$ & OR & IC- $95 \%$ & $p$ \\
\hline \multicolumn{6}{|c|}{ Total inability to move/bed } \\
\hline Yes & 08 & 72.7 & \multirow{2}{*}{4.762} & \multirow{2}{*}{$1.085-20.907$} & \multirow{2}{*}{$0.042 *$} \\
\hline No & 03 & 27.3 & & & \\
\hline \multicolumn{6}{|c|}{ Reluctance to move } \\
\hline Yes & 01 & 9.1 & \multirow{2}{*}{0.550} & \multirow{2}{*}{$0.059-5.126$} & \multirow{2}{*}{0.595} \\
\hline No & 10 & 90.9 & & & \\
\hline \multicolumn{6}{|c|}{ Limited variation of movement } \\
\hline Yes & 08 & 72.7 & \multirow{2}{*}{3.833} & \multirow{2}{*}{$0.879-16.711$} & \multirow{2}{*}{0.063} \\
\hline No & 03 & 27.3 & & & \\
\hline \multicolumn{6}{|c|}{ Strength, muscle mass control Decreased } \\
\hline Yes & 09 & 81.8 & \multirow{2}{*}{5.825} & \multirow{2}{*}{$1.110-30.559$} & \multirow{2}{*}{$0.025^{\star}$} \\
\hline No & 02 & 18.2 & & & \\
\hline \multicolumn{6}{|c|}{ Impaired motor skills } \\
\hline Yes & 09 & 81.8 & \multirow{2}{*}{7.200} & \multirow{2}{*}{$1.366-37.960$} & \multirow{2}{*}{$0.011 *$} \\
\hline No & 02 & 18.2 & & & \\
\hline
\end{tabular}

Source: Fieldresearch, 2012. decreased muscle mass, 09 (81.8\%) of them presented this clinical condition, with significance of $(p=0.025)$. Concerning impaired motor skills, 09 $(81.8 \%)$ of these patients presented it, with significance of ( $p=0.011$ ) (Table 5).

The extrinsic factor: pressure in the body was statistically significant ( $p=0.036)$, and $09(81.8 \%)$ of patients affected by PL presented areas of redness and/or printing marks in part of their bodies, caused by continuous pressure on the skin. It was noted that among the affected patients, 08 (72.7\%) of them presented skin adhesion to the surface of the mattress and/or bed, while the layers of subcutaneous tissue slide in the opposite direction. Statistical significant of ( $p=0.036)$ for friction and shear forces (Table 6).

Through a logistic regression technique it was found that COPD $(O R=11.85, I C-95 \%=1.79$ 78.29, $p=0.01$ ), Impaired motor coordination (OR $=10.848$; IC $-95 \%=1.329-88.562, p=0.026)$ and Sacrum $(O R=8.261$; IC-95\% = $1.056-64.614$, $p=0.044)$ were significantly associated with the presence of PL (Table 7).

Table 6. Occurrence of UP according to extrinsic factors: Evaluation of strength of pressure on the body and Evaluation of strength of friction and shear.

\begin{tabular}{|c|c|c|c|c|c|}
\hline Variables & $\mathrm{n}$ & $\%$ & OR & IC- $95 \%$ & $p$ \\
\hline \multicolumn{6}{|c|}{ Pressure force on the body } \\
\hline Yes & 09 & 81.8 & \multirow{2}{*}{5.25} & \multirow{2}{*}{$1.002-27.514$} & \multirow{2}{*}{$0.036^{*}$} \\
\hline No & 02 & 18.2 & & & \\
\hline \multicolumn{6}{|c|}{ Frictional force/shear force } \\
\hline Yes & 08 & 72.7 & \multirow{2}{*}{5.33} & \multirow{2}{*}{$1.209-23.536$} & \multirow{2}{*}{$0.036^{*}$} \\
\hline No & 03 & 27.3 & & & \\
\hline
\end{tabular}

Table 7. Variables in the final model of multivariate analysis. OR= Odds Ratio.

\begin{tabular}{|l|c|c|c|}
\hline \multicolumn{1}{|c|}{ Variables } & OR & IC- $95 \%$ & P \\
\hline COPD & 11.85 & $1.79-78.29$ & 0.01 \\
\hline Impaired motor skills & 10.848 & $1.329-88.562$ & 0.026 \\
\hline Sacrum & 8.261 & $1.056-64.614$ & 0.044 \\
\hline & \multicolumn{3}{|c}{ Source: Field research, 2012. } \\
\hline
\end{tabular}




\section{Discussion}

Several authors $[7,9]$ claim higher prevalence in males, though the findings corroborate the non-association with the emergence of $\mathrm{PL}$, perhaps because of the small number of people assessed.

Older age patients developed more $\mathrm{PL}$, and this is due to the fact that with increasing age there are several changes in the skin, with a reduction in its elasticity and texture, the frequency of cell replacement, time of the healing process, activities and mobility. It also occurs a decrease in body weight, which leads to exposure of bony prominences and decreased tissue ability to distribute pressure. There also occurs a reduction in peripheral sensitivity, directly interfering with the perception of pain [7, 10-13].

A relatively uncommon finding of this study was the association of COPD with PL. Few authors [7] approach to COPD specifically as a risk factor for the development of PL. What is known is that chronic respiratory complications generates the need of increased length of stay, which corresponds to an average of 14 days. It is reported that lung dysfunction affects oxygenation and blood flow to tissues, committing directly in peripheral tissue perfusion.

A study [3] carried out in two ICU found that among the diagnostic hypotheses of patients' hospitalization, the most frequent were respiratory (39.6\%), cardiac (20.8\%) and neurological (17.0\%) diseases, constituting therefore a set of diseases that aggravate the condition of patients and, therefore, require in most cases several days of hospitalization in ICU. Another study points to respiratory diseases as the second leading cause [13].

Most patients presented impaired mobility. The lowering of sensory perception decreases the sensation of feeling the pain and discomfort, and as a result this reduction results in the lack of stimulation to the patient moving in bed for relief, making it thus more likely the emergence of PL [10].

It is notorious that the patients under the influence of drugs are subject to low sensory per- ception and, consequently, struggling to mobilize, and more conducive to the emergence PL [10]. An example of drugs that reduce the feeling of pain and impair mobility are the painkillers and sedatives [12].

PL locations developed by patients during this study corroborate with studies of various authors that show that the sacrum region is the most prevalent for the emergence of $\mathrm{PL}$, because it is a region that takes greater pressure in patients when lying on the back position [10]. A study developed in China with inpatients pointed the sacrum, the heel and the iliac crests as the most often places to developing $\mathrm{PL}$ and that this result is consistent with those of other European countries [4].

The lack of mobility is one of the main risk factors for the development of $\mathrm{PL}$, leading to tissue injury due to the pressure on places of bony prominence which points to the need for greater attention by the multidisciplinary team to the bedridden and dependent patients on their vulnerability to the occurrence of pressure injuries [14].

The continuous use of drugs, such as sedatives and painkillers, although necessary, hamper the mobility and can contribute to the emergence of the PL [9-11.15]. These drugs reduce the sensitivity of normal pain stimulus, which leads the patient to try to relieve the pressure, in addition to promoting a relaxation, therefore patients remain longer in the same position, decreasing mobility, making them susceptible to prolonged pressure [9].

Hospitalizations in ICU are relatively larger than in other hospital environments, in addition to being a specific location for the care to people clinically more severe and/or unstable, that leads them to long periods of time on bedridden condition, which predisposes their bodies to withstand higher pressure. Body pressure force occurs when the skin is compressed between a bony protrusion and a hard surface by means of a perpendicular force resulting from the gravity action. The findings showed that the pressure force on the body and the force of 
friction/shear are closely connected to the development of PL.

In order to avoid this pressure in the patient's body, the proper positioning of the patient in bed, chair or wheelchair must be taken into account, considering: postural alignment, distribution of body weight, reducing the pressure on sensitive areas and the stability of the patient [14].

Friction and shear, factors present in patients with any degree of immobility, are considered to be significant risk factors for PL. The friction is created at a moment when the forces of two surfaces slide against each other, resulting in abrasion, that can often form bubbles. Shear strength occurs as a result of immobilization or incorrect placements, causing damage to deeper tissues [15].

\section{Conclusions}

This study demonstrated that the results obtained are in agreement with the literature, reflecting the relationship between the emergence of $\mathrm{PL}$ to their intrinsic and extrinsic risk factors, and predisposing conditions, as well as the incidence of $\mathrm{PL}$ in the ICU and its problematic for healthcare, however, it also showed significant and consistent association of COPD with the appearance of pressure injuries, which still appears little in the literature before the other intrinsic and extrinsic factors. The chronic obstructive pulmonary disease, impaired motor skills and evidenced bony prominence, specifically in the sacral region, were statistically significant factors in association with the development of pressure injuries.

The intrinsic risk factors for the emergence of the most evident PL were decreased pain sensitivity, reduced turgor and elasticity, evidenced bony prominence and impaired physical mobility. Extrinsic risk factors were the pressure force on the body and forces of friction and shear.

The limits of this study refer to the small sample, which represents only the studied reality, however, it is important not only for this one, but also for future searches with more robust methodologies, pointing safely and significantly the actual size of COPD as risk factor for the development of PL.

\section{References}

1. National Pressure Ulcer Advisory Panel [homepage on the internet]. National Pressure Ulcer Advisory Panel (NPUAP) announces a change in terminology from pressure ulcer to pressure injury and updates the stages of pressure injury [cited 2016 may 30]. Available from: http://www.npuap.org/nationalpressure-ulcer-advisory-panel-npuap-announces-a-changein-terminology-from-pressure-ulcer-to-pressure-injury-andupdates-the-stages-of-pressure-injury/

2. Rocha Filho DR, Oliveira DC, Carvalho ARB, Leal MG. Produção científica sobre as abordagens preventivas das úlceras por pressão. R. Interd [Internet]. 2013 [cited 2016 may 30]; 6(4):196204. Available from: http://revistainterdisciplinar.uninovafapi. edu.br/index.php/revinter/article/view/227

3. Fernandes NCS, Torres GV, Vieira D. Fatores de risco e condições predisponentes para úlcera de pressão em pacientes de terapia intensiva. Rev Eletr Enf. [Internet]. 2008 [cited 2016 may 30]; 10(3):733-46. Available from: http://www.fen.ufg.br/fen revista/v10/n3/pdf/v10n3a19.pdf

4. Jiang Q, Li X, Qu X, Liu Y, Zhang L, Su C et al. The incidence, risk factors and characteristics of pressure ulcers in hospitalized patients in China. Int J Clin Exp Pathol [Internet]. 2014 [cited 2016 may 30]; 7(5):2587-2594. Available from: http://www. ncbi.nlm.nih.gov/pmc/articles/PMC4069923/

5. Shaw LF, Chang P, Lee JF, Kung HY, Tung TH. Incidence and predicted risk factors of pressure ulcers in surgical patients: experience at a medical center in taipei, taiwan. BioMed Research International [Internet]. Volume 2014, Article ID 416896, 9 pages. Available from: http://dx.doi.org/10.1155/2014/416896

6. Cavalcante PS, Rossaneis MA, Haddad MCL, Gabriel CS. Healthcare quality indicators used in hospital nursing care management. Rev enferm UERJ, 2015; 23(6): 787-93. Available from: http://www.e-publicacoes.uerj.br/index.php/ enfermagemuerj/article/view/7052/16181

7. Bavaresco T, Medeiros RH; Lucena MF. Implantação da Escala de Braden em Uma Unidade de Terapia Intensiva de um Hospital Universitário. Rev. gaúch. enferm. [Internet]. 2011 [cited 2016 may 30]; 32(4):705-10. Available from: http://www.scielo.br/ pdf/rgenf/v32n4/v32n4a10.pdf

8. Sá-Silva JR, Almeida CD, Guindani JF. Pesquisa documental: pistas e metodologias. Rev. Brasileira de História \& Ciências Sociais [Internet]. 2009 [cited 2016 may 30]; 1(1):1-15. Available from: http://www.rbhcs.com/index arquivos/Artigo. Pesquisa\%20documental.pdf 
9. Fuman GF. Úlceras por Pressão: Incidência e Associação de Fatores de Risco em pacientes de um hospital universitário. Rev. enferm. UFPE On line [Internet]. 2010 [cited 2016 may 30]; 04(3):1506-514. Available from: http://www.revista.ufpe. br/revistaenfermagem/index.php/revista/article/viewFile/1148/ pdf 149

10. Rogenski NM, Kurcgant P. Incidência de úlceras por pressão após a implementação de um protocolo de prevenção. Rev. latinoam, enferm. [Internet]. 2012 [cited 2016 may 30]; 20(02):01-07. Available from: http://www.scielo.br/pdf/rlae/v20n2/pt 16.pdf

11. Gomes FSL et al. Fatores associados à úlcera por pressão em pacientes internados nos Centros de Terapia Intensiva de Adultos. Rev. Esc. Enferm. USP. [Internet]. 2010 [cited 2016 may 30]; 44(4):1070-6. Available from: http://www.scielo.br/pdf/ reeusp/v44n4/31.pdf

12. Alves AR. A Importância da Assistência de Enfermagem na Prevenção de Úlceras por Pressão no Paciente Hospitalizado. Rev. Instituto Ciência Saúde [Internet]. 2008 [cited 2016 may 30]; 26(4):397-402. Available from: http://www.unip.br/ comunicacao/publicacoes/ics/edicoes/2008/04 out dez/V26 N4 p397-402.pdf

13. Blanes L, Duarte IS, Calil JA, Ferreira LM. Avaliação clínica e epidemiológica das úlceras por pressão em pacientes internados no Hospital São Paulo. Rev. Assoc. Med. Bras. [Internet]. 2004 [cited 2016 may 30]; 50(2):182-187. Available from: http://www. scielo.br/pdf/ramb/v50n2/20781.pdf

14. Silva RB, Loureiro MDR, Frota OP, Ortega FB, Ferraz CCB. Qualidade da assistência de enfermagem em unidade de terapia intensiva de um hospital escola. Rev Gaúch. Enferm. [Internet]. 2013 [cited 2016 may 30]; 34(4):114-120. Available from: http:// seer.ufrgs.br/index.php/RevistaGauchadeEnfermagem/article/ view/36792

15. Luz SR. Lopacinski AC, Fraga R, Urban CA. Úlceras por Pressão. Rev. Geriatria e Gerontologia [Internet]. 2010 [cited 2016 may 30]; 4(1):36-43. Available from: http://sbgg.org.br/wp-content/ uploads/2014/10/2010-1.pdf
Publish in International Archives of Medicine

International Archives of Medicine is an open access journal publishing articles encompassing all aspects of medical science and clinical practice. IAM is considered a megajournal with independent sections on all areas of medicine. IAM is a really international journal with authors and board members from all around the world. The journal is widely indexed and classified Q1 in category Medicine. 